Auntie Emma always has me over for fish pie on Tuesdays with her four well-behaved sons. One of them lives in Italy, they have a fountain in the back garden, and Howard the youngest will make a first class insurance clerk and always sits next to me.

After dinner Uncle Rodney comes home and has a digestion tablet, then we all drink sherry, and the eldest two sons are already balding, which is definitely a sign they intend to have houses in Esher.

\title{
DISABILITY QUESTIONNAIRE
}

1. Do you consider yourself ready to work yet?

"No."

2. If no, give reasons:

"We11, I'm not very talented at office type jobs, but I have my pride, and if some middle class asshole starts making snide remarks I'm liable to bust them right in the mouth. But I wouldn't mind getting rehabilitated into The Army as a machine gun operator, or into a factory job where I had access to a sledgehammer so I could brain my enemies. Otherwise, I'd like working with innocent children."

NEW BOOK

At your boyfriend's house you're reading a book in which the pages are sometimes upsidedown, or the bottom line is missing or some of the words have fallen off the side. And even the most normal pages have a sudden sentence of nonsense words, or there's a lipstick mark, a half-smoked pack of cigarettes, smelly panties, a lewd pencilled note or pubic hair.

You've decided that either this is just one more avant garde novel or there's someone around you don't know the full story on. 